\title{
Cytomegalovirus pathogenesis in transplantation
}

\author{
JANE E GRUNDY, PHD, MRCPATH
}

\begin{abstract}
JE GRUNDY. Cytomegalovirus pathogenesis in transplantation. Can J Infect Dis 1993;4(Suppl C):11C17C. Cytomegalovirus (CMV) infection is an important cause of morbidity and mortality in the immunocompromised; however, even within this group of patients, infection with CMV is not synonymous with disease. A number of factors affect the pathogenicity of the virus. An understanding of the mechanisms by which CMV causes disease at different sites in the body, and of how that might vary with different patient groups, is essential to the design of stategies for the prevention and treatment of disease. This review discusses the factors which affect the occurrence and type of CMV disease in different patient populations, and considers some of the underlying mechanisms which might contribute to pathology.
\end{abstract}

Key Words: AIDS, Cytomegalovirus, Immunopathology, Pneumonitis, Transplantation

\section{Pathogenèse du cytomégalovirus dans la transplantation}

RÉSUMÉ: L'infection à CMV (cytomégalovirus) est une importante cause de morbidité et de mortalité chez le sujet immunocompromis; cependant, même dans cette population, l'infection à CMV n'est pas synonyme de maladie. Un nombre de facteurs affectent la pathogénicité du virus. La compréhension du mécanisme par lequel le CMV cause la maladie en différents points de l'organisme et de la façon dont cela peut varier selon les groupes de patients est essentielle à l'élaboration de stratégies prophylactiques et thérapeutiques contre la maladie. Cette synthèse passe en revue les facteurs qui affectent la survenue et le type de maladie à CMV chez diverses populations de patients et proposent certains mécanismes sous-jacents qui pourraient contribuer à la pathologie.

$\mathrm{C}$ YTOMEGalOVIRUS (CMV). A MEMBER OF THE HERPESVIRUS group, causes widespread infection in the community, but rarely causes disease in individuals with normal immunity. In the pretransplant era, congenital infection of the immunologically immature fetus was the most important clinical manifestation of CMV infection in humans $(1,2)$. However, since the advent of immunosuppressive therapy and transplantation, CMV has emerged as a major cause of morbidity and mortal- ity in transplant recipients (3-7). In addition, the appearance of the acquired immunodeficiency syndrome (AIDS) has generated an additional population of immunocompromised patients at high risk for CMV disease (8).

Although the clinical situations in which CMV is an important pathogen share the common feature of an immature or compromised immune system, the spectrum of disease in each patient group varies, especially with regard to the predominant organs affected $(9,10)$.

Division of Communicable Diseases, Royal Free Hospital School of Medicine, London, United Kingdom

Correspondence and reprints: Dr Jane E Grundy, Division of Communicable Diseases, Royal Free Hospital School of Medicine, London NW3 2PF, United Kingdom 
An understanding of the mechanisms by which CMV causes disease at different sites in the body, and of how that might vary with different patient groups, is essential to the design of strategies for the prevention and treatment of disease. This review discusses the factors which affect the occurrence and type of CMV disease in different patient populations, and considers some of the underlying mechanisms which might contribute to pathology. The focus is on CMV infection in the immunocompromised host; the reader is referred elsewhere for a discussion of congenital CMV infection (11).

\section{TYPE OF CMV INFECTION}

In transplant recipients, CMV infection can arise from two sources: an exogenous source of virus, usually via donor organs or administered blood products; or from reactivation of latent endogenous virus. Thus infection can be categorized as three types: primary, denoting infection with exogenous virus in a seronegative individual; reactivation, referring to reactivation of latent endogenous virus in a seropositive individual; or reinfection, denoting infection of a seropositive individual with a new strain of CMV from an exogenous source. The type of infection is an important factor in the pathogenesis of infection and the expression of symptomatic disease $(9,10)$.

Primary infection has been associated with disease following bone marrow transplantation (12) and all types of solid organ transplantation $(4,5,13)$. The incidence of primary infection in seronegative bone marrow transplant recipients has been dramatically reduced by the use of screened CMV-negative blood products $(14,15)$, or by using blood products depleted of granulocytes (14). Although transplanted bone marrow has been shown to transmit CMV infection $(14,16)$, this does not appear to be as important a source of primary infection in the seronegative recipient. Indeed it is likely that granulocytes and stromal cells in marrow preparations are responsible for any transmission of virus which does occur, and certain manipulations of the marrow, such as $\mathrm{T}$ cell depletion, which reduce the contamination with granulocytes and stromal cells, may also reduce transmission of CMV. In solid organ transplant recipients, primary infection can only be prevented by selecting seronegative donors for seronegative recipients (17), and while some centres do try to adopt such a 'matching policy' (18), this is often not practical when transplants are urgently needed, and furthermore it is not clear what effect the "matching for CMV before other factors, such as human leukocyte antigen typing, would have on the long term outcome for the patient (19). Thus primary CMV infection remains an important cause of disease in recipients of solid organ transplants.

Reactivation of latent endogenous virus is frequently associated with disease in the most severely immunocompromised patients. For example, it is clear that as primary infection has decreased with the use of screened blood products, the major clinical problems associated with CMV in bone marrow recipients are a result of reactivation of latent endogenous virus in seropositive recipients (14). In recipients of solid organ allografts, the frequency and severity of reactivation (as assessed in seropositive recipients with seronegative donors) both appear to be affected by the degree and type of immunosuppressive therapy $(4,20)$. Thus, a spectrum of disease severity is seen following CMV reactivation, usually from the most severe in bone marrow recipients to the least severe in renal transplant recipients.

Where seropositive recipients receive solid organs from seropositive donors, it is difficult to distinguish whether subsequent CMV infection results from reactivation of endogenous virus or reinfection with donor virus. This has only been distinguished in the case of paired renal transplant recipients with the same kidney donor, where restriction endonuclease analysis of viral DNA was used to type the CMV strains excreted posttransplantation (21-23). Since no two CMV strains have identical restriction patterns unless they are epidemiologically related, if both paired recipients excreted the same strain of CMV it could be assumed to have come from the common kidney donor. In the case of seropositive recipients, excretion of donor strain virus must represent reinfection. Reinfection with donor virus was demonstrated to occur (21-23), and to be associated with disease (23), although the incidence of symptomatic infection was less than following primary infection (23). In this particular study reactivation was usually asymptomatic, thus the clinical severity of CMV infection in this series of renal transplant recipients was: primary most severe, then reinfection, then reactivation (23).

In AIDS patients there is little information concerning which types of infection are associated with disease. The majority of male homosexual patients are CMV seropositive $(24,25)$, suggesting that reactivation may be an important cause of symptomatic CMV infection. However, excretion of multiple strains of CMV by the same individual has been observed in this patient group $(26,27)$, implicating a potentially pathogenic role for reinfection with new CMV strains.

\section{PATHOGENICITY OF CMV AT DIFFERENT BODY SITES}

CMV replicates in a variety of tissues throughout the body, but causes disease at only some of these sites, and even then only in certain patient groups $(9,10,28)$. The criteria for ascribing a pathogenic role for CMV at a particular body site has been discussed elsewhere $(9,28)$. The major sites of CMV pathogenicity in immunocompromised patients are summarized in Table 1. In transplant recipients, CMV disease is predominantly associated with the liver, the gut and the lungs. CMV pneumonitis is the most important complication of 
TABLE 1

Major sites of cytomegalovirus pathogenicity in immunocompromised patients

\begin{tabular}{|c|c|c|c|c|c|c|}
\hline \multicolumn{7}{|c|}{ Transplant recipients } \\
\hline Site of infection & Renal & Heart & Heart-lung & Liver & Marrow & AIDS patients \\
\hline Salivary gland & - & - & - & - & - & - \\
\hline Liver & + & + & + & + & + & + \\
\hline Gut & + & + & + & + & + & + \\
\hline Retina & + & NA & NA & NA & + & + \\
\hline Lung & + & + & + & + & + & - \\
\hline
\end{tabular}

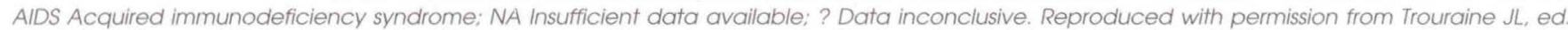
Transplantation and Clinical Immunology XXIII: Viruses and Transplantation. Amsterdam: Elsevier Science Publishers, 1991

CMV infection in allogeneic transplant recipients, with a mortality rate if untreated of greater than $85 \%$ in bone marrow recipients (29). CMV retinitis occurs relatively rarely in transplant recipients. In contrast, CMV retinitis is a common manifestation of CMV infection in AIDS patients (8). The latter group also has severe gastrointestinal disease; all parts of the gut from the esophagus to the anus can be involved. Neurological manifestations are also common in AIDS patients (30), but the contribution of CMV to the generation of this type of disease is controversial. CMV is not believed to have the same role as a pathogen in the lungs of AIDS patients as that observed in transplant recipients $(9,10,31,32)$, a subject which will be discussed further.

In solid organ transplant recipients the transplanted organ is frequently a particular focus of CMV-associated pathology, for example, CMV hepatitis is particularly common in liver transplant recipients (33). The virus is also thought to provoke graft rejection (9), and has been implicated as playing a pathogenic role in a variety of syndromes in transplant recipients which affect the transplanted organ (10), such as graft atherosclerosis in heart and heart-lung recipients $(34,35)$, or obliterative bronchiolitis in heart-lung recipients $(36,37)$. The kidney is not usually a site of CMV disease; however, there is speculation that CMV is sometimes involved in acute transplant glomerulopathy in renal transplant recipients (38). In bone marrow transplant recipients, CMV infection is associated with graft-versus-host disease $(12,39)$ and graft-versus-leukemia effects (40), although which is cause and which is effect is not clear. While these associations, and the role of CMV in graft rejection, remain controversial, it is of interest that these phenomena have two features in common: first, they involve the transplanted organ, and second, they are thought to have an immunopathological component.

\section{MECHANISM OF CMV PATHOGENICITY}

The mechanism by which CMV causes disease could be a direct consequence of viral replication and associated cytopathology, or an indirect effect due to host responses elicited in response to viral infection $(9,10)$. A combination of both factors is also possible. Some types of CMV disease can be effectively treated by antiviral chemotherapy, suggesting that the pathology was predominantly mediated by direct viral replication. Perhaps the best example of this is CMV retinitis which can be acutely treated with ganciclovir (8), although the formation of scar tissue may impair vision; cessation of treatment leads to exacerbation of disease. CMV hepatitis also appears to respond to antiviral treatment (8), and thus is also probably mostly a consequence of direct viral cytopathology. In contrast, a controlled trial of treatment of gastrointestinal disease with ganciclovir in bone marrow recipients had marginal effects (41). In the latter case the duration of treatment might have been insufficient or it is possible that the disease had an immunopathological component which would not have been affected by the antiviral therapy. In the case of CMV pneumonitis in allogeneic transplant recipients, CMV disease appears to be related more directly to some component of the immune response to the virus than to viral replication per se $(9,32)$, a topic discussed in more detail below.

\section{PATHOGENICITY OF CMV IN THE LUNGS OF IMMUNOCOMPROMISED PATIENTS}

As mentioned above, CMV interstitial pneumonitis is a major complication of CMV infection following transplantation of both solid organs and bone marrow. The best data on the mortality of untreated CMV pneumonitis come from bone marrow recipients, where mortality rates of greater than $85 \%$ were observed (29). Although the precise mortality rates are not as well defined in recipients of solid organs, they are also high. The incidence of CMV pneumonitis differs markedly among the different types of bone marrow transplants, being predominantly a feature of infection in recipients of allogeneic bone marrow, where incidences of 17 to $19 \%$ have been reported $(39,42-44)$. In contrast, CMV pneumonitis is much less common (4 to 6\%) in recipients of autologous marrow (43-45), and was not observed in 100 recipients of syngeneic marrow from identical twin 
donors (42). In allogeneic marrow recipients, CMV pneumonitis was associated with graft-versus-host disease $(12,39)$. These data suggested that some immunological component of the graft-versus-host reaction was involved in the generation of CMV pneumonitis in the allogeneic marrow recipients (32), this being lacking in the syngeneic recipients. On the basis of these and other clinical observations, together with a series of data from the murine model of CMV infection, a hypothesis was constructed for the pathogenesis of CMV pneumonitis (32). This hypothesis is discussed in detail elsewhere $(9,32)$, but the major tenet is that CMV pneumonitis in allogeneic transplant recipients is an immunopathological condition, associated with a $\mathrm{T}$ cell response induced by CMV replication in the lung. Thus viral replication per se was necessary but not sufficient for the generation of CMV pneumonitis. This proposal was supported by the fact that antiviral chemotherapy alone failed to prevent death from CMV pneumonitis in the marrow recipients, despite reducing viral titres in the lung to almost undetectable levels (46).

The situation in AIDS patients is quite different, where the presence of CMV in the lungs of patients with pneumonitis did not increase mortality, despite the fact that they did not receive any treatment for the CMV infection (31). This clearly contrasts with the high mortality of CMV pneumonitis in transplant recipients, and this apparent lack of pathogenicity of CMV in the lungs of AIDS patients was explained in the original hypothesis by the suggestion that AIDs patients might lack the pathogenic T cell response to CMV in the lung (32). Further studies in our centre have compared the attack rate of CMV pneumonitis post-transplantation in transplant recipients with that in human immunodeficiency virus (HIV) infected patients on an episode per patientmonth basis. HIV infected patients were defined as being at risk when CD4-positive peripheral blood $\mathrm{T}$ cell counts fell below $0.2 \times 10^{9} / \mathrm{mL}$ (47). Interestingly, there was no significant difference in the attack rate of episodes of pneumonitis in which CMV was found in the lung in 207 allogeneic transplant recipients (0.62 episodes per 100 patient-months) and $138 \mathrm{HIV}$ infected patients (0.80 episodes per 100 patient-months) (47). In contrast HIV infected patients had significantly more episodes of pneumonitis associated with Pneumocystis carinii than allogeneic transplant recipients (1.67 compared with $0.27, \mathrm{P}<0.05$ ), despite the fact that pneumocystis prophylaxis was much more common in HIV infected patients (47). Thus the apparent relative lack of pathogenicity of CMV in AIDS patients compared with transplant recipients is unlikely to relate to higher attack rates in the latter group.

Subsequent studies in our centre have compared the effect of the presence of CMV in the lungs on the severity of the pneumonitis episode in allogeneic transplant recipients with that in AIDS patients (48). It was found that the severity of pneumonitis, scored accord- ing to clinical and radiological criteria, was greater in transplant recipients when CMV was present in the lung than when the virus was absent, whereas no difference was seen in AIDS patients (48). Thus our data suggest that CMV infection in the lungs of AIDS patients does not usually significantly contribute to the severity or mortality of pneumonitis episodes. Interestingly, of the AIDS patients at our centre with pneumonitis where CMV was the only pathogen found, the only two patients in whom we felt that CMV was contributing to lung pathology had peripheral blood CD4-positive cell counts above $0.2 \times 10^{9} / \mathrm{mL}$ (49), suggesting that in HIV infected patients with sufficient preservation of CD4positive $\mathrm{T}$ cells, a pathogenic $\mathrm{T}$ cell response to CMV could develop in the lungs. Since CMV infection in the lung is usually a relatively late manifestation of AIDS, finding CMV in the lungs of a patient with pneumonitis with high CD4 counts is a probably a relatively rare event. Our data also suggest that CD4-positive T cells may play an important role in the pathogenesis of CMV pneumonitis in allogeneic transplant recipients.

It can be concluded, therefore, that CMV interstitial pneumonitis is not universally seen in immunocompromised patients, but is closely associated with a host $\mathrm{T}$ cell response which is stimulated or augmented by CMV infection in the lung. The pathogenic immune response involved with the pathogenesis of CMV pneumonitis appears to be associated with or related to allogeneic responses to transplanted tissue or to the graft-versus-host response.

\section{EFFECT OF CMV INFECTION ON HOST IMMUNE RESPONSES}

CMV infection has multiple effects on the host immune response, and has been shown both to suppress and augment immune responsiveness in vitro and in vivo. Such effects have been reviewed elsewhere (50,51). When considering how CMV infection might contribute to immunopathology in transplant recipients, it is of interest that while many immune responses are suppressed in the acute phase of CMV infection, studies in the murine model of CMV have shown that alloresponsiveness is augmented (52), as is the graft-versus-host response (53-55). As mentioned above, acute graft-versus-host disease is an important risk factor for CMV pneumonitis. Together these data suggest that CMV infection and graft-versus-host disease accentuate each other. Graft-versus-host disease is a condition which is associated with activated killer cells (56), and which is often preceded by large increases in cytokine production (8). Previous data from our group have shown that interferon-gamma and tumour necrosis factor production by peripheral blood leukocytes after marrow transplantation is augmented by exposure to CMV infected bone marrow fibroblasts (57). In addition we have suggested that CMV induced interleukin-2 production generates non-major histo- 
compatibility complex (MHC) restricted cytotoxic cells which may contribute to marrow hypoplasia (58). Our studies showed that interleukin-2 activated peripheral blood mononuclear cells from bone marrow recipients killed uninfected and CMV infected fibroblasts equally, suggesting that local production of interleukin-2 activated killer cells generated during CMV infection would damage uninfected as well as infected marrow fibroblasts, thereby possibly compromising hemopoietic factor production by marrow fibroblasts (58). Thus our hypothesis is that CMV provides a trigger which initiates pathological host responses or acts synergistically with ongoing responses such as graft-versus-host disease $(9,10,32,50,57,58)$.

In focusing attention on possible ways in which CMV infection might potentiate destructive host responses, we studied the effect of the virus on the expression of immunologically important cell surface molecules. Our results showed that CMV infection of fibroblasts resulted in a dramatic decrease in the cell surface level of class I human leukocyte antigens $(59,60)$, which may affect cytotoxic $\mathrm{T}$ cell recognition of infected cells. In contrast, we found that CMV increased the cell surface expression of the adhesion molecules LFA-3 and ICAM1 (60,61), molecules which are important for both MHC-restricted and non-MHC restricted cytotoxicity, as well as leukocyte trafficking.

The increased expression of adhesion molecules was accompanied by a parallel increase in the adhesion of CD2-positive, but not CD2-negative, leukocytes to the infected fibroblasts (62). This is of great interest since this lymphocyte subset is composed of $\mathrm{T}$ cells and CD16-positive natural killer cells. All subpopulations of CD2-positive lymphocytes, namely CD3-positive, CD4positive and CD8-positive cells, demonstrated increased adhesion to CMV-infected fibroblasts. Since CD2 is the ligand for LFA-3, and LFA-3 was up-regulated on the CMV infected fibroblasts, our data suggested that the CD2-LFA-3 interaction was in part responsible for the increased lymphocyte adherence, a proposal supported by the finding that monoclonal antibodies specific for LFA-3 blocked the CD2-positive lymphocyte binding (62). Since lymphocytes can be activated by the CD2 pathway, our data raise the question of whether the interaction between CD2 on lymphocytes and LFA-3 on CMV infected fibroblasts affects the activation state of lymphocytes (62).

The peak expression of adhesion molecules and increase in lymphocyte adherence coincides with the time at which infected cells have been shown to be good targets for natural killer cells (63), and it is of interest that the enhanced susceptibility to lysis was reported to be associated with increased binding of the effector cells to the CMV infected target cells (63). Thus our findings of increased adhesion molecule expression and increased lymphocyte adhesion may well have important biological consequences. In addition, supernatants from CMV infected fibroblasts, or co-cultures of infected fibroblasts and leukocytes, could transfer increased leukocyte adherence to uninfected fibroblasts (62). These data suggest that the virus might provoke leukocyte responses to uninfected as well as infected cells, thereby possibly contributing to tissue damage, and that CMV-induced cytokine release might accentuate inflammation in vivo.

An initial stage of inflammation is the adhesion of leukocytes to vascular endothelium. Thus any alteration in this adhesive interaction, or in subsequent steps in the migration of leukocytes through the vessel wall, could have important effects on the inflammatory process. Others have recently described the increased adherence of polymorphonuclear leukocytes to cultures of endothelial cells infected with CMV (64). This effect was attributed to up-regulation of the adhesion molecule ELAM-1 on the surface of uninfected cells by cytokines, such as interleukin-1, released from CMV infected cells. In these cultures only about $10 \%$ of the endothelial cells were actually infected with CMV (64). Thus, as with our fibroblast system, mediators released from CMV infected endothelial cells increased the adherence of particular leukocyte subpopulations to bystander uninfected cells. We are currently studying the effect of CMV infection of endothelial cells on the adherence of subpopulations of lymphocytes. If endothelial cell infection is accompanied by similiar increased binding of lymphocytes to that observed with fibroblasts, profound effects on inflammation and immune responses at sites of CMV infection could be envisaged.

\section{CONCLUSIONS}

In summary, a number of factors affect the pathogenicity of CMV in immunocompromised patients. First, the type of infection - primary, reinfection or reactivation. Second, the patient group; differences are seen between transplant recipients and AIDS patients, and between different types of transplants, in the body site at which CMV causes disease. The transplanted organ is often a focus for pathology. Third, the mechanism of pathogenicity can be either a direct effect of viral replication and cytopathology or due to the host response induced by CMV, or possibly a combination of these mechanisms. The ability of CMV to enhance adhesion molecule expression, increase lymphocyte adhesion and augment cytokine production by leukocytes in vitro, may well contribute to inflammation and immunopathology during CMV infection in vivo.

\section{REFERENCES}

1. Weller TH. The cytomegaloviruses: Ubiquitous agents with protean clinical manifestations. II. N Engl J Med 1971;285:267-74

2. Weller TH. The cytomegaloviruses: Ubiquitous agents with protean clinical manifestations. I. N Engl J Med 1971;285:203-14.

3. Rubin RH. Impact of cytomegalovirus infection on organ 
transplant recipients. Rev Infect Dis 1990;12(Suppl 7):S754-66.

4. Rubin RH, Tolkoff-Rubin NE, Oliver D, et al. Multicenter seroepidemiologic study of the impact of cytomegalovirus infection on renal transplantation. Transplantation 1985;40:243:9.

5. Singh N, Dummer JS, Kusne S, et al. Infections with cytomegalovirus and other herpesviruses in 121 liver transplant recipients: Transmission by donated organ and the effect of OKT3 antibodies. J Infect Dis 1988;158:124-31.

6. Ho M. Epidemiology of cytomegalovirus infections. Rev Infect Dis 1990;12(Suppl 7):S701-10.

7. Dummer JS, White LT, Ho M, Griffith BP, Hardesty RL, Bahnson HT. Morbidity of cytomegalovirus infection in recipients of heart or heart-lung transplants who received cyclosporine. J Infect Dis 1985;152:1182-91.

8. Treatment of serious cytomegalovirus infections with 9-(1,3-dihydroxy-2-propoxymethyl) guanine in patients with AIDS and other immunodeficiencies. Collaborative DHPG Treatment Study Group. N Engl J Med 1986;314:801-5.

9. Grundy JE. Virologic and pathogenetic aspects of cytomegalovirus infection. Rev Infect Dis 1990;12(Suppl 7):S711-9.

10. Grundy JE. The biology of cytomegalovirus infection. In: Touraine JL, ed. Transplantation and Clinical Immunology XXIII: Viruses and Transplantation. Amsterdam: Elsevier, 1991:89-96.

11. Alford CA, Stagno S, Pass RF, Britt WJ. Congenital and perinatal cytomegalovirus infections. Rev Infect Dis 1990:12(Suppl 7):S745-53.

12. Meyers JD, Flournoy N, Thomas ED. Risk factors for cytomegalovirus infection after human marrow transplantation. J Infect Dis 1986;153:478-88.

13. Gorensek MJ, Stewart RW, Keys TF, McHenry MC, Goormastic M. A multivariate analysis of the risk of cytomegalovirus infection in heart transplant recipients. J Infect Dis 1988;157:515-22.

14. Bowden RA, Meyers JD. Prophylaxis of cytomegalovirus infection. Semin Hematol 1990;27:17-21.

15. Bowden RA, Sayers M, Gleaves CA, Banaji M, Newton B, Meyers JD. Cytomegalovirus-seronegative blood components for the prevention of primary cytomegalovirus infection after marrow transplantation. Considerations for blood banks. Transfusion 1987;27:478-81.

16. Bowden RA, Sayers M, Flournoy N, et al. Cytomegalovirus immune globulin and seronegative blood products to prevent primary cytomegalovirus infection after marrow transplantation. N Engl J Med 1986;314:1006-10.

17. Williams PF, Wreghitt T, Joysey V, Evans DB, Calne RY. Cytomegalovirus matching in renal transplantation. Lancet 1988;ii:569. (Lett)

18. Henell KR, Chou S, Norman DJ. Use of cytomegalovirus-seropositive donor kidneys in seronegative patients: Results of prospective serotesting and matching in one center. Transplant Proc 1989;21:2082-3.

19. Griffiths PD, Grundy JE, Ali A, et al. Cytomegalovirus matching in renal transplantation. Lancet 1988;ii:971. (Lett)

20. Andreone PA, Olivari MT, Elick B, et al. Reduction of infectious complications following heart transplantation with triple-drug immunotherapy. J Heart Transplant 1986;5:13-9.

21. Grundy JE, Super M, Griffiths PD. Reinfection of a seropositive allograft recipient by cytomegalovirus from donor kidney. Lancet 1986;i:159-60. (Lett)
22. Grundy JE, Super M, Lui S, Sweny P, Griffiths PD. The source of cytomegalovirus infection in seropositive renal allograft recipients is frequently the donor kidney. Transplant Proc 1987;19:2126-8.

23. Grundy JE, Lui SF, Super M, et al. Symptomatic cytomegalovirus infection in seropositive kidney recipients: Reinfection with donor virus rather than reactivation of recipient virus. Lancet 1988;ii:132-5.

24. Collier AC, Meyers JD, Corey L, Murphy VL, Roberts PL, Handsfield HH. Cytomegalovirus infection in homosexual men. Relationship to sexual practices, antibody to human immunodeficiency virus, and cell-mediated immunity. Am J Med 1987;82:593-601.

25. Mann SL, Meyers JD, Holmes KL, Corey L. Prevalence and incidence of herpesvirus infections among homosexually active men. J Infect Dis 1984;149:1026-7.

26. Drew WL, Sweet ES, Miner RC, Mocarski ES. Multiple infections by cytomegalovirus in patients with acquired immunodeficiency syndrome: Documentation by Southern blot hybridization. J Infect Dis 1984;150:952-3.

27. Collier AC, Chandler SH, Handsfield HH, Corey L, McDougall JK. Identification of multiple strains of cytomegalovirus in homosexual men. J Infect Dis 1989; 159:123-6.

28. Griffiths PD, Grundy JE. The status of CMV as a human pathogen. Epidemiol Infect 1988;100:1-15.

29. Meyers JD, Flournoy N, Thomas ED. Nonbacterial pneumonia after allogeneic marrow transplantation: A review of ten years' experience. Rev Infect Dis 1982;4:1119-32.

30. Pinching AJ. Neurological aspects of the acquired immune deficiency syndrome. J R Coll Physicians Lond 1988;22:136-9.

31. Millar AB, Patou G, Miller RF, et al. Cytomegalovirus in the lungs of patients with AIDS. Respiratory pathogen or passenger? Am Rev Respir Dis 1990;141:1474-7.

32. Grundy JE, Shanley JD, Griffiths PD. Is cytomegalovirus interstitial pneumonitis in transplant recipients an immunopathological condition? Lancet 1987;ii:996-9.

33. Dummer JS. Cytomegalovirus infection after liver transplantation: Clinical manifestations and strategies for prevention. Rev Infect Dis 1990;12(Suppl 7):S767-75.

34. Grattan MT, Moreno-Cabral CE, Starnes VA, Oyer PE, Stinson EB, Shumway NE. Cytomegalovirus infection is associated with cardiac allograft rejection and atherosclerosis. JAMA 1989;261:3561-6.

35. McDonald K, Rector TS, Braulin EA, Kubo SH, Olivari MT. Association of coronary artery disease in cardiac transplant recipients with cytomegalovirus infection. Am J Cardiol 1989;64:359-62.

36. Keenan RJ, Lega ME, Dummer JS, et al. Cytomegalovirus serologic status and postoperative infection correlated with risk of developing chronic rejection after pulmonary transplantation. Transplantation 1991:51:433-8.

37. Fend F, Prior C, Margreiter R, Mikuz G. Cytomegalovirus pneumonitis in heart-lung transplant recipients: Histopathology and clinicopathologic considerations. Hum Pathol 1990;21:918-26.

38. Boyce NW, Hayes K, Gee D, et al. Cytomegalovirus infection complicating renal transplantation and its relationship to acute transplant glomerulopathy. Transplantation 1988;45:706-9.

39. Wingard JR, Mellits ED, Sostrin MB, et al. Interstitial pneumonitis after allogeneic bone marrow transplantation. Nine-year experience at a single institution. Medicine (Baltimore) 1988;67:175-86.

40. Jacobsen N, Badsberg JH, Lonnqvist B, et al. Graft-versus-leukaemia activity associated with 
CMV-seropositive donor, post-transplant CMV infection, young donor age and chronic graft-versus-host disease in bone marrow allograft recipients. The Nordic Bone Marrow Transplantation Group. Bone Marrow Transplant 1990:5:413-8.

41. Reed EC, Wolford JL. Kopecky KJ, et al. Ganciclovir for the treatment of cytomegalovirus gastroenteritis in bone marrow transplant patients. A randomized, placebocontrolled trial. Ann Intern Med 1990:1 12:505-10.

42. Applebaum FR, Meyers JD, Fefer A, et al. Nonbacterial nonfungal pneumonia following marrow transplantation in 100 identical twins. Transplantation 1982;33:265-8.

43. Wingard JR, Sostrin MB, Vriesendorp HM, et al. Interstitial pneumonitis following autologous bone marrow transplantation. Transplantation 1988;46:61-5.

44. Wingard JR, Chen DY, Burns WH, et al. Cytomegalovirus infection after autologous bone marrow transplantation with comparison to infection after allogeneic bone marrow transplantation. Blood 1988;71:1432-7.

45. Pecego R, Hill R, Appelbaum FR, et al. Interstitial pneumonitis following autologous bone marrow transplantation. Transplantation 1986;42:515-7.

46. Shepp DH, Dandliker PS, de-Miranda P, et al. Activity of 9-[2-hydroxy-1-(hydroxymethyl) ethoxymethyl] guanine in the treatment of cytomegalovirus pneumonia. Ann Intern Med 1985; 103:368-73.

47. Squire SB, Morris JK, Lipman MCI, Grundy JE, Johnson MA. A comparison of attack rate of infective pneumonitis between HIV-infected patients and allogeneic transplant recipients. Proceedings of the European Respiratory Society Meeting. Vienna, 1992.

48. Squire SB, Bray DH, Bagdades EK, et al. Expression of phenotypic markers for alveolar macrophage subpopulations is associated with severity in CMV pneumonitis. In: Landini MP, ed. Progress in Cytomegalovirus Research. Amsterdam: Elsevier, 1991;299-302.

49. Squire SB, Lipman MCI, Bagdades EK, et al. Severe cytomegalovirus pneumonitis in HIV infected patients with higher than average CD4 counts. Thorax 1992;47:301-4.

50. Grundy JE. The immune response to cytomegalovirus. In: Landini MP, ed. Progress in Cytomegalovirus Research. Amsterdam: Elsevier, 1991:143-55.

51. Griffiths PD, Grundy JE. Molecular biology and immunology of cytomegalovirus. Biochem J 1987;241:313-24.

52. Grundy JE, Shearer GM. The effect of cytomegalovirus infection on the host response to foreign and hapten-modified self histocompatibility antigens. Transplantation 1984;37:484-90.

53. Grundy JE, Shanley JD, Shearer GM. Augmentation of graft-versus-host reaction by cytomegalovirus infection resulting in interstitial pneumonitis. Transplantation 1985;39:548-53.

54. Via CS, Shanley JD, Weatherly BR, Lang P, Shearer GM. Altered threshold for the induction of graft-versus-host immunodeficiency following murine cytomegalovirus infection. Host and donor contributions. Transplantation 1988;46:298-302.

55. Via CS, Shanley JD, Shearer GM. Synergistic effect of murine cytomegalovirus on the induction of acute graft-vs-host disease involving MHC class I differences only. Analysis of in vitro T cell function. J Immunol 1990;145:3283-9.

56. Hokland M, Jacobsen N, Ellegaard J, Hokland P. Natural killer function following allogeneic bone marrow transplantation. Very early reemergence but strong dependence of cytomegalovirus infection. Transplantation 1988;45:1080-4.

57. Duncombe AS, Meager A, Prentice HG, et al. Gammainterferon and tumor necrosis factor production after bone marrow transplantation is augmented by exposure to marrow fibroblasts infected with cytomegalovirus. Blood 1990;76: 1046-53.

58. Duncombe AS, Grundy JE, Prentice HG, Brenner MK. Activated killer cells may contribute to cytomegalovirus induced hypoplasia after bone marrow transplantation. Bone Marrow Transplant 1991;7:81-7.

59. Barnes PD, Grundy JE. Down regulation of the Class I HLA heterodimer and $\beta 2$-microglobulin on the suvface of cells infected with cytomegalovirus. J Gen Virol 1992;73:2395-405.

60. Hutchinson K, Eren E, Grundy JE. Expression of ICAM-1 and LFA-3 following cytomegalovirus infection. In: Landini MP, ed. Progress in Cytomegalovirus Research. Amsterdam: Elsevier, 1991:267-70.

61. Grundy JE, Downes KL. Up-regulation of LFA-3 and ICAM-1 on the surface of fibroblasts infected with cytomegalovirus. Immunology 1993;78:405-12.

62. Grundy JE, Pahal GS, Akbar AN. Increased adherence of CD2 positive peripheral blood lymphocytes to cytomegalovirus infected fibroblasts is blocked by anti-LFA-3 antibody. Immunology 1993;78:413-8.

63. Borysiewicz LK, Rodgers B, Morris S, Graham S, Sissons JG. Lysis of human cytomegalovirus infected fibroblasts by natural killer cells: Demonstration of an interferonindependent component requiring expression of early viral proteins and characterization of effector cells. J Immunol 1985;134:2695-2701.

64. Span AH, Mullers W, Miltenburg AM, Bruggeman CA. Cytomegalovirus induced PMN adherence in relation to an ELAM-1 antigen present on infected endothelial cell monolayers. Immunology 1991;72:355-60. 


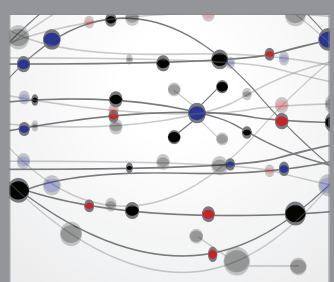

The Scientific World Journal
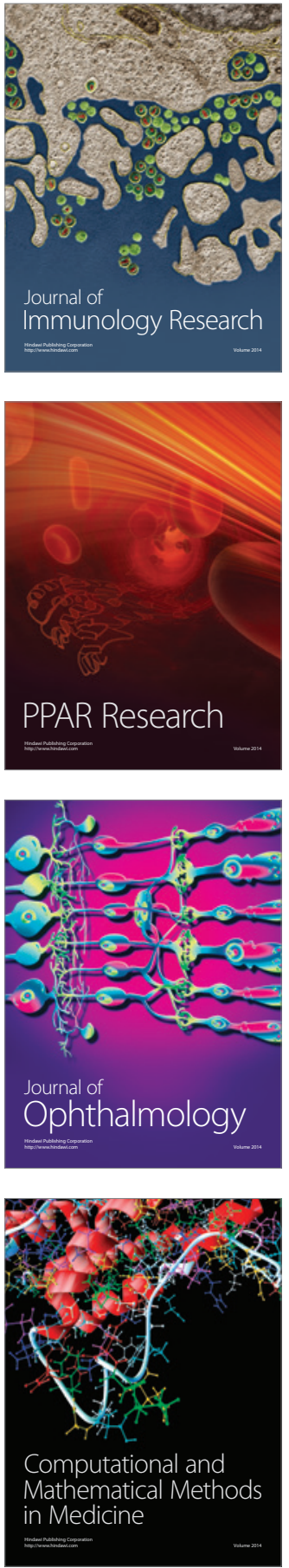

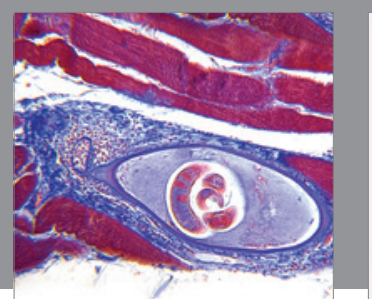

Gastroenterology Research and Practice

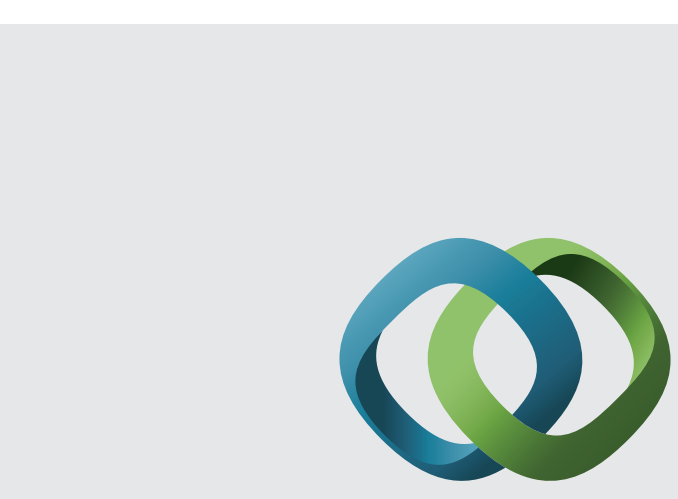

\section{Hindawi}

Submit your manuscripts at

http://www.hindawi.com
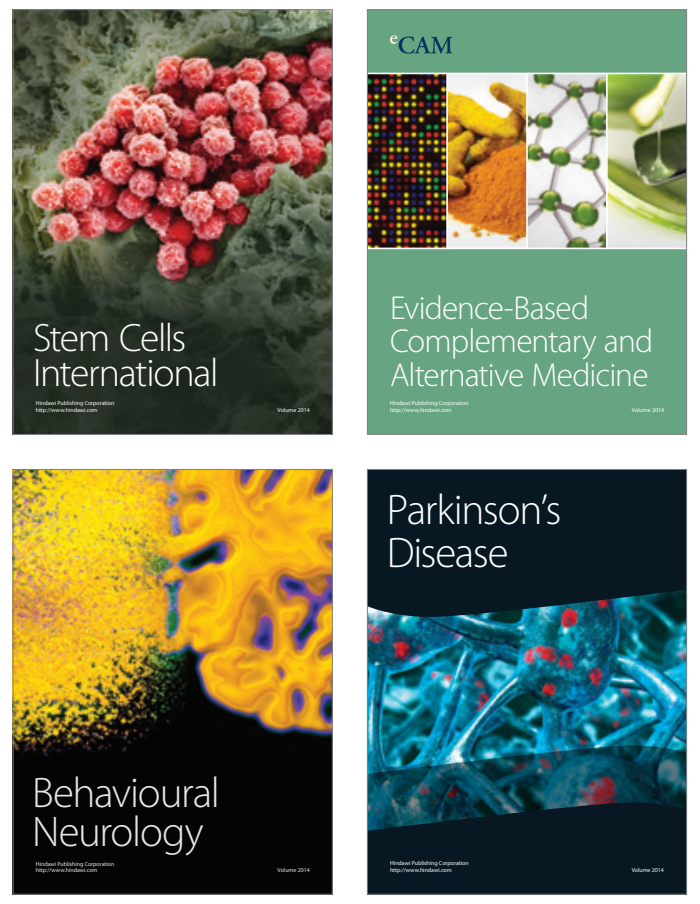
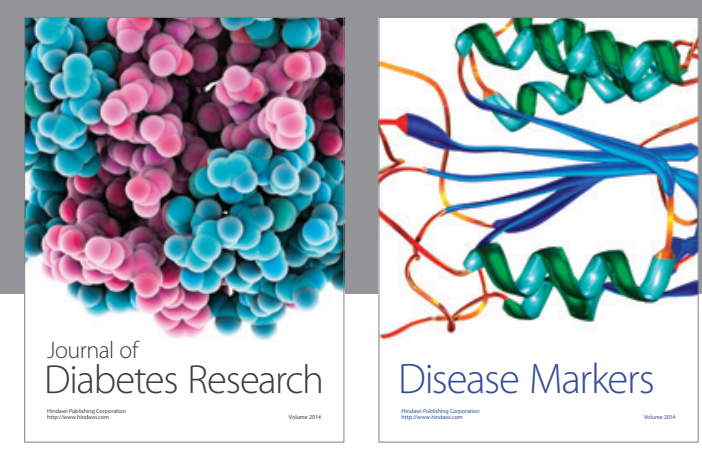

Disease Markers
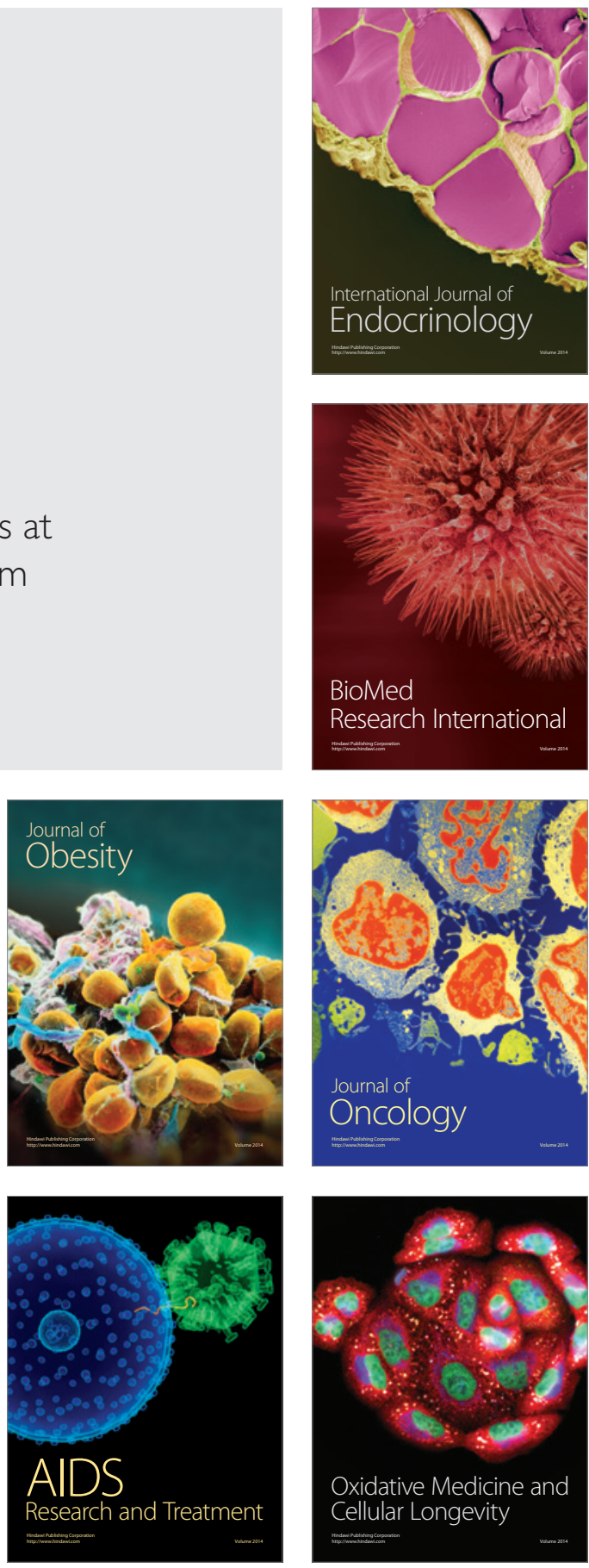